\title{
Stream Temperature Response to $50 \%$ Strip-Thinning in a Temperate Forested Headwater Catchment
}

\author{
Dinh Quynh Oanh ${ }^{1, * \mathbb{C}}$, Takashi Gomi ${ }^{2}$, R. Dan Moore ${ }^{3}$, Chen-Wei Chiu ${ }^{2}$, Marino Hiraoka ${ }^{2,4}$, Yuichi Onda ${ }^{5}$ \\ and Bui Xuan Dung ${ }^{6}$ \\ 1 Symbiotic Science of Environment and Natural Resources, United Graduate School of Agriculture Science, \\ Tokyo University of Agriculture and Technology, Tokyo 183-8509, Japan \\ 2 Graduate School of Agriculture, Tokyo University of Agriculture and Technology, Tokyo 183-8509, Japan; \\ gomit@cc.tuat.ac.jp (T.G.); ccwei97@gmail.com (C.-W.C.); hiraoka-m573bt@pwri.go.jp (M.H.) \\ 3 Department of Geography, University of British Columbia, Vancouver, BC V6T-1Z2, Canada; \\ dan.moore@ubc.ca \\ 4 Erosion and Sediment Control Research Group, Public Works Research Institute, Tsukuba 305-8516, Japan \\ 5 Center for Research in Isotopes and Environmental Dynamics, University of Tsukuba, \\ Tsukuba 305-8577, Japan; onda@geoenv.tsukuba.ac.jp \\ 6 Department of Environmental Management, Vietnam National University of Forestry, Xuan Mai, \\ Hanoi 13417, Vietnam; buixuandungfuv@gmail.com \\ * Correspondence: quynhoanhvfu@gmail.com; Tel.: +81-42-367-5751
}

Citation: Oanh, D.Q.; Gomi, T.; Moore, R.D.; Chiu, C.-W.; Hiraoka, M.; Onda, Y.; Dung, B.X. Stream Temperature Response to $50 \%$ Strip-Thinning in a Temperate Forested Headwater Catchment. Water 2021, 13, 1022. https:// doi.org/10.3390/w13081022

Academic Editor: Thomas Meixner

Received: 16 February 2021

Accepted: 5 April 2021

Published: 8 April 2021

Publisher's Note: MDPI stays neutral with regard to jurisdictional claims in published maps and institutional affiliations.

Copyright: (c) 2021 by the authors. Licensee MDPI, Basel, Switzerland. This article is an open access article distributed under the terms and conditions of the Creative Commons Attribution (CC BY) license (https:/ / creativecommons.org/licenses/by/ $4.0 /)$.

\begin{abstract}
Stream temperature is a critical parameter for understanding hydrological and biological processes in stream ecosystems. Although a large body of research has addressed the effects of forest harvesting on stream temperature, less is known about the responses of stream temperature to the practice of strip-thinning, which produces more coherent patches of shade and sunlight areas. In this study, we examined stream temperature response to $50 \%$ strip-thinning in a 17 ha headwater catchment. The thinning lines extended through the riparian zone. Paired-catchment analysis was applied to estimate changes in daily maximum, mean, and minimum stream temperatures for the first year following treatment. Significant effects on daily maximum stream temperature were found for April to August, ranging from $0.6{ }^{\circ} \mathrm{C}$ to $3.9^{\circ} \mathrm{C}$, similar to the magnitude of effect found in previous studies involving 50\% random thinning. We conducted further analysis to identify the thermal response variability in relation to hydrometeorological drivers. Multiple regression analysis revealed that treatment effects for maximum daily stream temperature were positively related to solar radiation and negatively related to discharge. Frequent precipitation during the summer monsoon season produced moderate increases in discharge (from 1 to $5 \mathrm{~mm} \mathrm{day}^{-1}$ ), mitigating stream temperature increases associated with solar radiation. Catchment hydrologic response to rain events can play an important role in controlling stream thermal response to forest management practices.
\end{abstract}

Keywords: stream temperature; strip-thinning; paired-catchment analysis; headwater stream; forest harvesting

\section{Introduction}

Stream temperature is an important indicator for understanding hydrological processes such as groundwater inflows [1] and groundwater-surface exchange in hyporheic zones [2]. In particular, because of tight linkages between hillslopes, riparian zones, and stream channels in headwater streams [3], stream temperature dynamics can be sensitive to hydrological processes in adjacent hillslopes and riparian zones. Changes in flow conditions (i.e., subsurface flow and groundwater inflow), as well as shading patterns along streams, alter stream heating processes [4,5]. Stream temperature is also one of the key variables for biological processes such as the distribution, abundance, metabolism, and growth rates of aquatic organisms in headwater streams [6,7]. 
Studies over the last five decades have revealed that changes in riparian forest condition influence stream temperature in headwater streams around the world (e.g., [8]), primarily due to the increase in solar radiation reaching the stream [9]. For instance, Harris [10] showed that increases in daily maximum stream temperature in summer increased up to $11.6^{\circ} \mathrm{C}$ in the first year after harvest in the coastal Pacific Northwest of North America. Webb and Crisp [11] showed that recovery of riparian vegetation and increases in shading after 4 years of coniferous plantation in the UK decreased monthly mean maximum stream temperature by $5{ }^{\circ} \mathrm{C}$. In Indonesia, Carlson et al. [12] reported that stream temperature increased up to $2.1^{\circ} \mathrm{C}$ after the conversion of native forest to oil palm plantation because of changes in shading patterns along riparian zones. Removal of Rhododendron understory in a southern Appalachian catchment increased daily maximum stream temperature by up to $2.6^{\circ} \mathrm{C}$ because of the increases in canopy gaps, although the treatment effect was variable among sites and years [13].

Responses of stream temperature to forest harvesting in riparian zones vary depending on the types of riparian management [9]. A number of studies found that buffer retention consistently reduced the magnitude of postharvest temperature increases following clear cut harvesting (e.g., [14-17]). The magnitude of postharvest thermal response also varies with hydrogeomorphic characteristics of a stream and its catchment. For example, Gomi et al. [18] found that, for clear-cut harvesting with no buffer, the increase in maximum daily temperature ranged among streams from about $2{ }^{\circ} \mathrm{C}$ to about $8{ }^{\circ} \mathrm{C}$. In that study, the lowest increase occurred for an incised, narrow stream that experienced substantial bank shading, whereas the highest increase occurred for a weakly incised stream fed by a small wetland that was exposed by the harvest. Janisch et al. [19] found that spatially intermittent streams, usually characterized by coarse-textured bed sediments, tended to be thermally unresponsive. Thermal response to harvest in the Oregon Coast Range was also related to different internal hydrological processes of catchments underlain by resistant lithology [20].

Thermal responses to timber harvesting vary on multiple time scales. On a multiyear time scale, treatment effects of forest harvesting decline through time as riparian vegetation develops and shade recovers (e.g., $[18,21,22])$. On a seasonal time scale, the thermal influence of harvest tended to be minimal during winter in a coastal rain and rain-on-snow dominated catchment $[18,23]$, reflecting the reduction of insolation by low solar angles and cloud cover, in addition to the dominant influence of advective energy input associated with hillslope runoff [24]. In contrast, treatment effects can vary substantially from day to day during warm day spells in summer, when vertical energy exchanges become a more significant component of the stream heat budget and streamflow remains low $[18,23,25]$.

The day-to-day variability of the treatment response should depend positively on the magnitude of energy inputs to the streams and negatively with stream discharge. Strong positive relations were found between the treatment effect and daily air temperature for three of four streams that experienced clear-cut harvesting with no buffer, with substantial variability between spring and summer [18]. A number of studies have demonstrated that stream temperature sensitivity to energy inputs is moderated by stream discharge (e.g., [26,27]). However, no studies have examined the sensitivity of postharvest stream temperature increases to stream discharge. This relation is important in the context of climatic warming, and the projected declines in summer precipitation and streamflow in many regions such as the Pacific Northwest of North America [28], which could increase the magnitude of postharvest stream warming.

Variable-retention or thinning treatments have been widely applied for striking a balance between wood production and ecological conservation, and for improving the wood quality of remaining trees $[29,30]$. Variable retention and thinning, which removes selected trees within a cut-block, provide intermediate levels of shade as compared to clear-cutting with and without riparian buffers. For instance, partial-retention harvesting of $50 \%$ of standing trees in riparian zones increased daily maximum stream temperature by up to $4.4{ }^{\circ} \mathrm{C}$ in Ontario, Canada [31] and $5.5^{\circ} \mathrm{C}$ in British Columbia, Canada [23]. 
Strip-thinning is a unique harvesting practice for effective timber removal while maintaining retention compared to conventional single-tree thinning (e.g., random and selective thinning) [32]. Removal of trees within linear strips is less time-consuming than selecting individual trees for removal, and is also more efficient for yarding timber to roads, skid trails, or landings [33]. In contrast to single-tree selection methods, which create scattered patterns of shade along a stream, strip-thinning produces more coherent patches of shade and sunlight areas [34]. However, the postharvest stream temperature response to strip-thinning has not previously been assessed through experimental approach involving pre- and postharvest data.

The objective of this study was to quantify the effects of strip-thinning on water temperature in a headwater stream using a paired-catchment experimental approach. The preharvest regressions are reasonable for identifying postharvest treatment effects. We documented the effects on daily maximum, mean, and minimum stream temperatures for one year after $50 \%$ strip-thinning. In addition to detecting and quantifying the magnitude of the thermal response, we conducted analyses to support the attribution of the thermal response variability in relation to hydrometeorological drivers, and with a specific focus on the role of streamflow.

\section{Materials and Methods}

\subsection{Study Site}

This study was conducted in two forested headwater catchments, $\mathrm{K}_{\mathrm{T}}(17.1 \mathrm{ha})$ and $\mathrm{K}_{\mathrm{C}}$ (8.9 ha), located in the area of Mt. Karasawa, Tochigi Prefecture, Japan $\left(36^{\circ} 22^{\prime} \mathrm{N}, 139^{\circ} 36^{\prime} \mathrm{E}\right.$; Figure $1 \mathrm{a}) . \mathrm{K}_{\mathrm{T}}$ catchment was subjected to the thinning treatment, while $\mathrm{K}_{\mathrm{C}}$ catchment was maintained as a control (no thinning). The climate in this area is moist and temperate with $1234 \pm 196$ (mean \pm standard deviation) $\mathrm{mm}$ mean annual precipitation and $14 \pm 0.5^{\circ} \mathrm{C}$ mean air temperature, based on an automated climate station located $3 \mathrm{~km}$ southwest of our study site (1994 to 2013 in Sano AMeDAS-Automatic Meteorological Data Acquisition System). High and intense precipitation occurs during the monsoon season (Baiu season) from May to July, and from August to October in association with typhoons. The study catchments range in elevation from 130 to $260 \mathrm{~m}$ a.s.l. [35]. Both catchments are underlain by sedimentary rock consisting of sandstone, chert, slate, mudstone, and shale. Stands of 20- to 50-year-old Japanese cedar (Cryptomeria japonica) and cypress (Chamaecyparis obtuse) dominate along the streams and up to the middle and upper parts of hillslopes. The ridgeline within the catchment is covered by mixture of broadleaf (e.g., Quercus serrata) and red pine (Pinus densiflora) forests. Dominant understory vegetation was evergreen shrubs (e.g., Cleyera japonica and Ardisia japonica) and Japanese aucuba (Aucuba japonica) before thinning. Stream channels have a mean gradient $6^{\circ}\left(2^{\circ}\right.$ standard deviation), bankfull widths from 0.5 to $1.5 \mathrm{~m}$ and wetted widths from 0.2 to $1.0 \mathrm{~m}$. Channel morphology includes pool-riffle and step-pool units [36] formed by boulders, cobbles and gravel.

Thinning in $\mathrm{K}_{\mathrm{T}}$ catchment was conducted from July to December 2011 by removing two lines of plantation trees (Figures 1 and 2). Stand density before thinning was 2198 stems ha $^{-1}$, whereas stand density became 1099 stems ha $^{-1}$ with a basal area of $26.2 \mathrm{~m}^{2} \mathrm{ha}^{-1}$ after $50 \%$ strip-thinning [37]. Thinning extended from the upper hillslope to the riparian zones (Figure 2). All thinned trees were cut by chainsaw and cable-yarded to the road and/or skid trail. Logging roads were located at the middle of the hillslope in $\mathrm{K}_{\mathrm{T}}$ catchment and in the upper hillslope in $\mathrm{K}_{\mathrm{C}}$ catchment (Figure 1a). An old logging road and new skid trail were reactivated and/or installed at the bottom of the valley [35]. After thinning, fern species (Gleichenia japonica), evergreen shrubs (e.g., Cleyera japonica and Ardisia japonica), Japanese aucuba (Aucuba japonica), and herbs and grasses (Carex lanceolate and Trachelospermum asiaticum) dominated [38]. We defined the period from 30 June 2010 to 1 July 2011 as "prethinning" and from 1 January to 31 December 2012, as "post-thinning". The period of forest operation with clearing understory vegetation and stand removal from July to December 2011 was considered as "during thinning operation". 
(a) Study site and monitoring

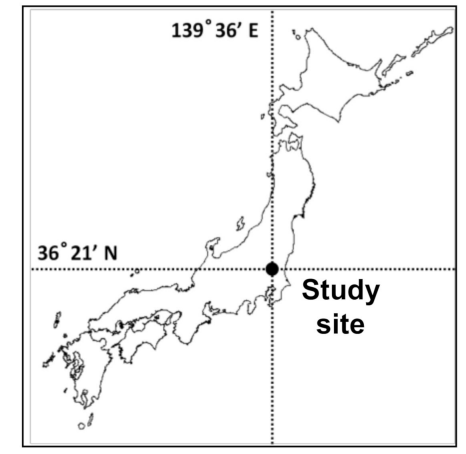

(b) Aerial image
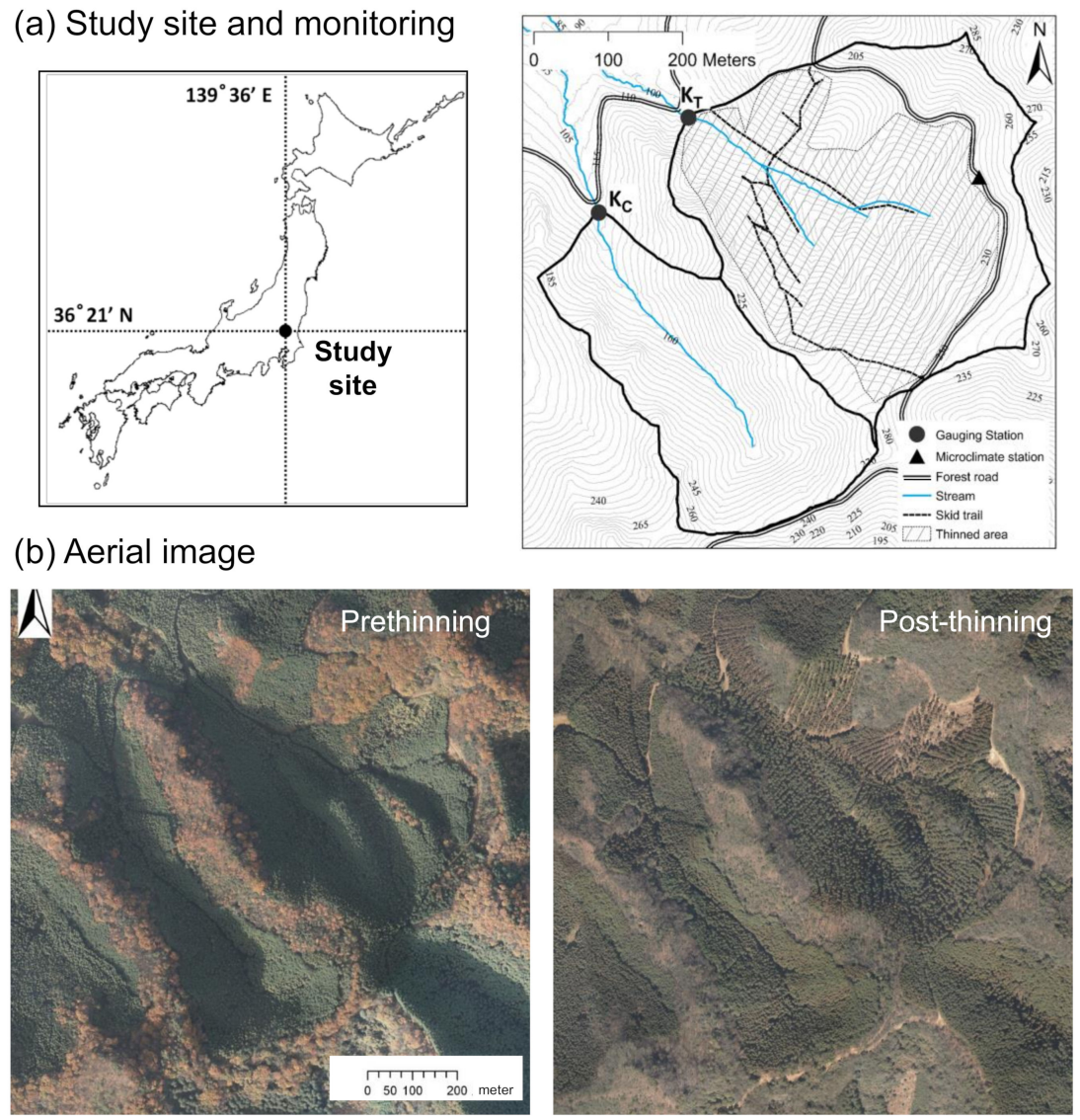

Figure 1. (a) Locations of study site and monitoring stations; (b) aerial images of study catchments before and after thinning.

Prethinning
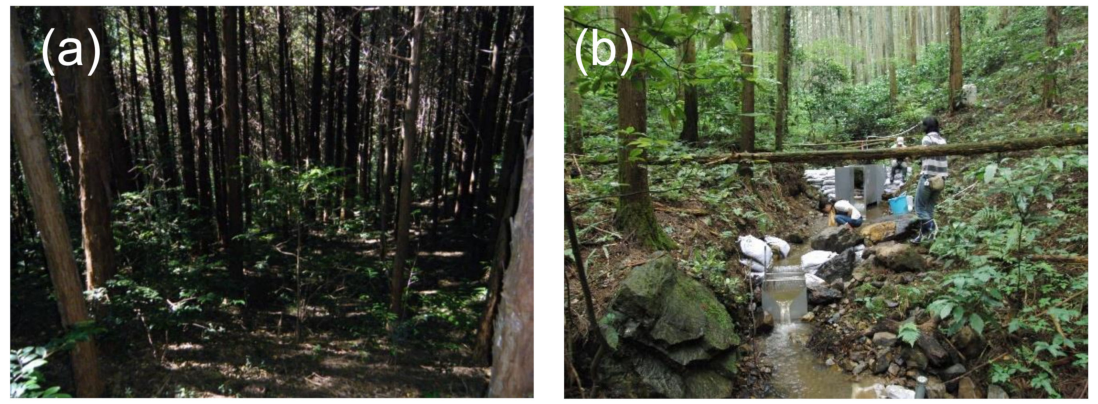

\section{Post-thinning}
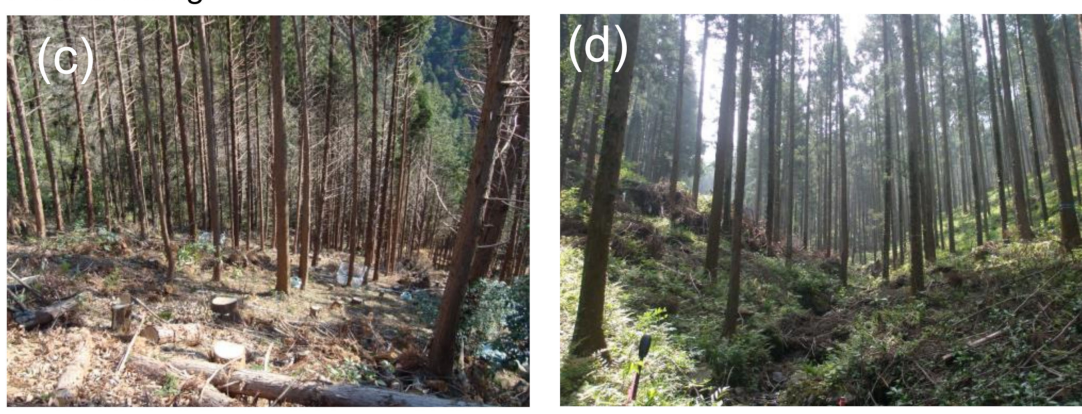

Figure 2. Overview of (a) hillslope and (c) riparian conditions before thinning and (c) hillslope and (d) riparian condition after thinning. In photo $(\mathbf{b})$, one can also see the monitoring station of the $\mathrm{K}_{\mathrm{T}}$ catchment with combination of Parshall flume and box type V-notch weir. 


\subsection{Monitoring}

Discharge and stream temperature were monitored at the outlets of catchments $K_{C}$ and $\mathrm{K}_{\mathrm{T}}$ from April 2010. Discharge was measured using a combination of V-notch weirs for low to moderate flow and Parshall flumes for high flow (Figure 2b). In the $K_{T}$ catchment, we used a $90^{\circ} \mathrm{V}$-notch weir and one-foot-wide Parshall flume, while a $60^{\circ} \mathrm{V}$-notch weir and 5 -inch-wide Parshall flume were installed at the $\mathrm{K}_{\mathrm{C}}$ catchment. Approximately $75 \%$ of flow data were estimated using the V-notch weirs and 25\% using the Parshall flumes. TruTrack water level loggers (TruTrack WT-HR 1000, Trutrack Ltd, Christchurch, New Zealand) recorded stage height every $10 \mathrm{~min}$ at both the weirs and flumes. Discharge through the V-notch weirs was measured using the volumetric method to develop the stage-discharge relationships. Discharge through the Parshall flumes was calculated using a formula based on flume dimensions and observed water depth $[39,40]$.

Continuous water temperature data at 10-min intervals were obtained by TruTrack loggers with $\pm 0.3^{\circ} \mathrm{C}$ precision. We also measured water temperature using Onset Tidbit water temperature data logger with $\pm 0.2^{\circ} \mathrm{C}$ precision (HOBO Water Temp v2, Onset Computer Corporation, Bourme, MA, USA) to confirm the accuracy of TruTrack logger. Water temperature measured by TruTrack loggers agreed with Tidbit data with a mean of the absolute values of the differences of $0.3{ }^{\circ} \mathrm{C}$. We calculated daily maximum, minimum, and mean stream temperatures based on 10-min data.

Meteorological data were monitored using an automated weather station (HOBO U30NRC Weather Station; Onset Computer Corporation, MA, USA) located at an open site at $250 \mathrm{~m}$ a.s.l. in the $\mathrm{K}_{\mathrm{T}}$ catchment (Figure 1). Precipitation $(\mathrm{mm})$, solar radiation $\left(\mathrm{W} \mathrm{m}^{-2}\right)$, air temperature $\left({ }^{\circ} \mathrm{C}\right)$, relative humidity $(\%)$, and wind speed $\left(\mathrm{m} \mathrm{s}^{-1}\right)$ were recorded every $5 \mathrm{~min}$. All sensors were placed at $2 \mathrm{~m}$ height above the ground. Daytime mean solar radiation, air temperature, relative humidity, and wind speed were calculated based on data from 6:00 to 18:00 [37]. Daytime mean values were determined by averaging the $5 \mathrm{~min}$ data.

We obtained 339 days with complete data coverage in the pre-thinning period (27 days were missing data in both the $\mathrm{K}_{\mathrm{T}}$ and $\mathrm{K}_{\mathrm{C}}$ catchments) and 366 days in the post-thinning period from 1 January 2012 to 31 December 2012. Complete stream temperature records were available for analysis. However, equipment malfunction resulted in 39 days of missing data ( $4.3 \%$ of total data) for the climate station in the post-thinning period. Discharge data were not available for 41 (4.5\% of total data) and 33 days (3.6\% of total data) in the $\mathrm{K}_{\mathrm{T}}$ and $\mathrm{K}_{\mathrm{C}}$ catchments, respectively.

Canopy openness of the riparian forest was estimated by taking hemispherical photographs $50 \mathrm{~cm}$ above stream surface using a Nikon D40 camera equipped with a Sigma $8 \mathrm{~mm}$ fisheye lens. Prior to taking photographs, the camera was mounted on a tripod and was oriented to the north. Hemispherical images were taken at the $\mathrm{K}_{\mathrm{T}}$ and $\mathrm{K}_{\mathrm{C}}$ catchments on 16 December 2010, 16 December 2011, and 4 December 2012, for the pre-thinning, during operation, and post-thinning periods, respectively. Gap Light Analyzer software (GLA, version 2) was used to analyze hemispherical images [41].

\subsection{Paired-Catchment Analysis of Stream Temperature Responses}

Paired-catchment analysis was applied to detect the effects of thinning on daily mean, maximum, and minimum stream temperatures [25]. We fit the following model using daily stream temperature data for the pre-thinning period:

$$
y_{t}=\beta_{0}+\beta_{1} x_{t}+\beta_{2} \sin (2 \pi j / T)+\beta_{3} \cos (2 \pi j / T)+\varepsilon_{t}
$$

where $y_{t}$ is daily maximum, mean, or minimum temperatures at day $t$ from the treated catchment $\mathrm{K}_{\mathrm{T}}, x_{t}$ is the corresponding temperature variables at day $t$ from the control catchment $K_{C}, \beta_{0}, \beta_{1}, \beta_{2}$, and $\beta_{3}$ are coefficients to be determined by regression, $j$ is the day of year ( $j=1$ corresponds to 1 January), and $T=365.25$ is the number of days in a year [18]. 
The sine and cosine terms are included to account for seasonality in the residuals [42]. The error term, $\varepsilon_{t}$, was modeled as an autoregressive process of order " $k$ ", expressed as:

$$
\varepsilon_{t}=\rho_{1} \varepsilon_{t-1}+\rho_{2} \varepsilon_{t-2}+\ldots+\rho_{k} \varepsilon_{t-k}+u_{t}
$$

where $\rho_{k}$ is the autocorrelation coefficient for the error terms at a lag of $k$ days, $\varepsilon_{t-k}$ is the error term $k$ days before day $t$, and $u_{t}$ is a random disturbance. The value of $k$ was determined based on finding the lowest value of Akaike's information criterion (AIC) [43]. The pre-thinning calibration was performed using the arima() function in the $\mathrm{R}$ programming language [23].

We used the preharvest regression to predict what the stream temperatures in the treated catchment $\mathrm{K}_{\mathrm{T}}$ would have been for the post-thinning period had the treatment not occurred. The apparent changes in stream temperature resulting from the impacts of forest thinning were estimated as follows:

$$
T_{e}=y_{t}-\hat{y}_{t}
$$

where $T_{e}$ is the treatment effect $\left({ }^{\circ} \mathrm{C}\right)$ and $y_{t}$ is the observed stream temperature in the $\mathrm{K}_{\mathrm{T}}$ catchment on day $t$ and $\hat{y}_{t}$ is the predicted temperature on day $t$, based on the fitted regression model.

Prediction intervals were calculated using Monte Carlo simulation [6] using a confidence level of $95 \%$. The uncertainty among the estimated parameters in the regression model for 1000 realizations was generated by function rmvnnorm() in the tmonorm package in base $\mathrm{R}$ ( $\mathrm{R}$ Development Core Team, 2019) to account for the variance-covariance structure of the parameter estimates.

Significance of the treatment effects was determined by applying the binomial distribution to the number of days on which the observed temperature fell outside the $95 \%$ prediction limits [44]. Under the null hypothesis of no treatment effect, one would expect to find $k_{\exp }=n \times p$ exceedances, where $k_{\exp }$ is the expected number of exceedances, $n$ is the number of days, and $p$ is the probability of exceedance $(0.05$ for $95 \%$ prediction intervals). For large samples, the normal approximation to the binomial can be applied, and the probability associated with finding the observed number of exceedances, or more, is equal to the probability of sampling a random normal deviate greater than or equal to $z=\left(k-k_{\text {exp }}\right) / \sqrt{n p(1-p)}$, where $k$ is the observed number of exceedances.

\subsection{Analysis of Hydrometeorological Controls}

We examined factors controlling the variability of treatment effects using pairwise rank correlation analysis and multiple linear regression. Factors were selected using the underlying physical principle that stream temperature changes are positively related to surface energy exchange and inversely related to stream depth [9]. Explanatory variables therefore included the following meteorological controls on stream-surface energy fluxes: daytime mean solar radiation $\left(\mathrm{W} \mathrm{m}^{-2}\right)$, daily mean air temperature $\left({ }^{\circ} \mathrm{C}\right)$, daily mean vapor pressure $\left(e_{a}, \mathrm{kPa}\right)$ and daily mean wind speed $\left(\mathrm{m} \mathrm{s}^{-1}\right)$.

Daily mean air temperature is related to both incident longwave radiation and, in conjunction with wind speed, the sensible heat flux. Daytime mean air vapor pressure $\left(e_{a}\right)$ is related to the latent heat exchange [45]. Air vapor pressure was calculated as:

$$
e_{a}=e_{s}\left(T_{a}\right) \times \frac{R H}{100}
$$

where $\mathrm{RH}$ is the relative humidity $(\%)$ and $e_{S}\left(T_{a}\right)$ is the saturation vapor pressure as a function of air pressure, calculated as:

$$
e_{s}\left(T_{a}\right)=0.611 \times \exp \left(\frac{17.27 T_{a}}{T_{a}+237.26}\right)
$$


Daily stream discharge $\left(\mathrm{mm} \mathrm{day}^{-1}\right)$ was also included in the analysis because it is related to stream depth [46]. In addition, higher stream discharge is typically associated with higher lateral inflow and advective heat transport [24], as well as higher in-stream velocities and thus reduced exposure time to energy inputs. We used the mean daily discharge instead of maximum or minimum because thermal responses of water tended to be associated with the mean condition of parameter in a given day. Analysis focused on the period from 1 April to 30 September, which was the period dominated by significant treatment effects.

We tested the association between treatment effects and hydrometeorological drivers using Spearman rank order correlation analysis. Rank correlation was used because it does not require assumptions about linearity of the relation or normality of data distributions.

Prior to conducting the regression analysis, all variables were standardized by subtracting the mean value and dividing by the standard deviation in order to assess the relative influence of each factor on treatment effects [47]. A stepwise regression using both forward and backward selection based on AIC was used to select the significant factors controlling the variability of treatment effects [48]. The final model with the lowest AIC score was selected and only explanatory variables significant at $p$-value $<0.05$ were retained. Multicollinearity was examined using the variance inflation factor (VIF). We used $\mathrm{VIF}<5$ for indicating the absence of significant multicollinearity [49]. Data processing and analysis were carried out using the $\mathrm{R}$ programming language ( $\mathrm{R}$ Development Core Team, 2019).

\section{Results}

\subsection{Canopy Openness}

Riparian canopy openness of the $\mathrm{K}_{\mathrm{T}}$ and $\mathrm{K}_{\mathrm{C}}$ catchments was similar in the pre-thinning period (Figure 3). During the strip-thinning operation, the mean canopy openness of the $\mathrm{K}_{\mathrm{T}}$ catchment became higher than that during the prethinning period with $25.9 \% \pm 0.8 \%$, while that of the $\mathrm{K}_{\mathrm{C}}$ catchment remained similar to that during prethinning at $11.1 \% \pm 4.3 \%$ (Figure 3). One year after thinning, the mean canopy openness of the $\mathrm{K}_{\mathrm{T}}$ catchment was higher than that of the $\mathrm{K}_{\mathrm{C}}$ catchment.

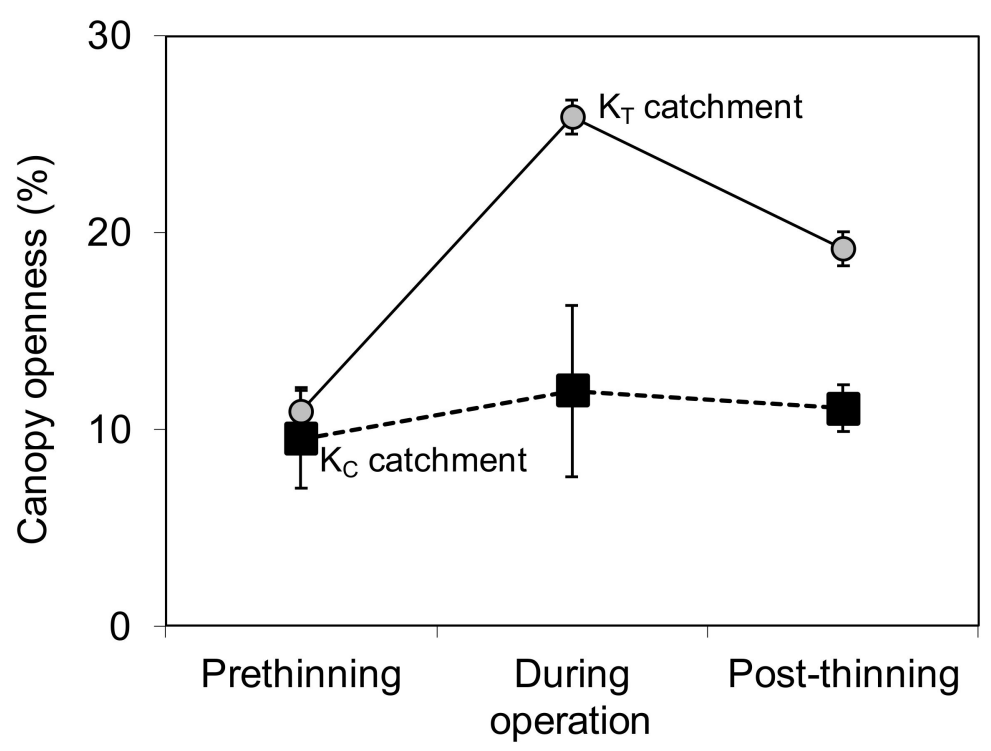

Figure 3. The changes in canopy openness $(\%)$ in the treated $\left(\mathrm{K}_{\mathrm{T}}\right)$ and control $\left(\mathrm{K}_{\mathrm{C}}\right)$ catchments during our monitoring period. Prethinning, during-operation, and post-thinning canopy openness was measured on 16 December 2010, 16 December 2011, and 4 December 2012, respectively. 


\subsection{Climatic Conditions}

At the AMeDAS Sano climate station, mean air temperature during the monitoring periods was similar to the mean value of air temperature over the past 20 years. Daily air temperatures in the post-thinning period were slightly higher than those in the prethinning period (Table 1). Annual precipitation at AMeDAS Sano climate station in 2010, 2011, and 2012 were 1363, 1371, and $1218 \mathrm{~mm}$, compared to the 20-year average of $1234 \mathrm{~mm}$, that is, the prethinning and during-operation periods were wetter than the average year, while the post-thinning tended to be drier.

Table 1. Summary of air temperature, stream discharge, and stream temperatures.

\begin{tabular}{|c|c|c|c|}
\hline & Prethinning & During Thinning Operation & Post-Thinning \\
\hline Total rainfall (mm) & 1230 & 1040 & 1295 \\
\hline \multicolumn{4}{|l|}{ Air temperature $\left({ }^{\circ} \mathrm{C}\right)$} \\
\hline Max & 37.9 & 37.9 & 38.6 \\
\hline Mean & 14.2 & 18.9 & 15.1 \\
\hline SD & 8.7 & 6.9 & 8.3 \\
\hline Min & -4.6 & 0.0 & -5.7 \\
\hline \multicolumn{4}{|l|}{ Discharge (mm day $\left.{ }^{-1}\right)$} \\
\hline \multicolumn{4}{|l|}{$K_{T}$ catchment } \\
\hline Max & 14.6 & 44.3 & 44.9 \\
\hline Mean & 0.8 & 2.6 & 1.2 \\
\hline $\mathrm{SD}$ & 1.6 & 6.3 & 2.9 \\
\hline Min & 0.1 & 0.2 & 0.1 \\
\hline \multicolumn{4}{|l|}{$K_{C}$ catchment } \\
\hline Max & 38.2 & 39.0 & 28.8 \\
\hline Mean & 0.8 & 2.2 & 0.9 \\
\hline SD & 3.0 & 5.8 & 2.1 \\
\hline Min & 0.1 & 0.2 & 0.1 \\
\hline \multicolumn{4}{|l|}{ Stream temperature $\left({ }^{\circ} \mathrm{C}\right)$} \\
\hline \multicolumn{4}{|l|}{$K_{T}$ catchment } \\
\hline Max & 22.3 & 22.4 & 26.2 \\
\hline Mean & 11.5 & 14.8 & 12.2 \\
\hline SD & 5.6 & 4.8 & 6.4 \\
\hline Min & 1.8 & 3.1 & 0.9 \\
\hline \multicolumn{4}{|l|}{$K_{C}$ catchment } \\
\hline Max & 21.5 & 20.8 & 21.5 \\
\hline Mean & 11.8 & 14.5 & 11.7 \\
\hline SD & 4.8 & 4.1 & 5.3 \\
\hline Min & 2.8 & 4.2 & 1.8 \\
\hline
\end{tabular}

\subsection{Hydrological Processes and Stream Temperature}

Runoff responded quickly to precipitation and was similar in both catchments (Figure 4). Total runoff from the $\mathrm{K}_{\mathrm{T}}$ catchment increased from $255 \mathrm{~mm}$ in the prethinning to $430 \mathrm{~mm}$ in the post-thinning period, while for the $\mathrm{K}_{\mathrm{C}}$ catchment, total runoff was 280 and $340 \mathrm{~mm}$ in pre- and post-thinning periods, respectively. The mean daily discharge of $\mathrm{K}_{\mathrm{C}}$ catchment was similar between the prethinning and post-thinning periods, while the mean daily discharge of $K_{\mathrm{T}}$ catchment was $50 \%$ higher in the post-thinning (Table 1). Maximum prethinning discharge was $14.6 \mathrm{~mm}_{\text {day }}{ }^{-1}$ in the $\mathrm{K}_{\mathrm{T}}$ catchment and $38.2 \mathrm{~mm}_{\text {day }}{ }^{-1}$ in the $\mathrm{K}_{\mathrm{C}}$ catchment, which occurred on 2 July 2010 ( $28.4 \mathrm{~mm}^{-1 a y^{-1}}$ total precipitation). The highest post-thinning discharge for $\mathrm{K}_{\mathrm{T}}\left(44.9 \mathrm{~mm}\right.$ day $\left.^{-1}\right)$ and $\mathrm{K}_{\mathrm{C}}\left(28.8 \mathrm{~mm}^{-1 a y^{-1}}\right)$ occurred on 3 May 2012 during a storm event with $126.8 \mathrm{~mm}$ day $^{-1}$ rainfall. Minimum daily discharge with less than $1.0 \mathrm{~mm}$ day $^{-1}$ occurred during winter periods when precipitation became low. 
(a) Discharge and precipitation

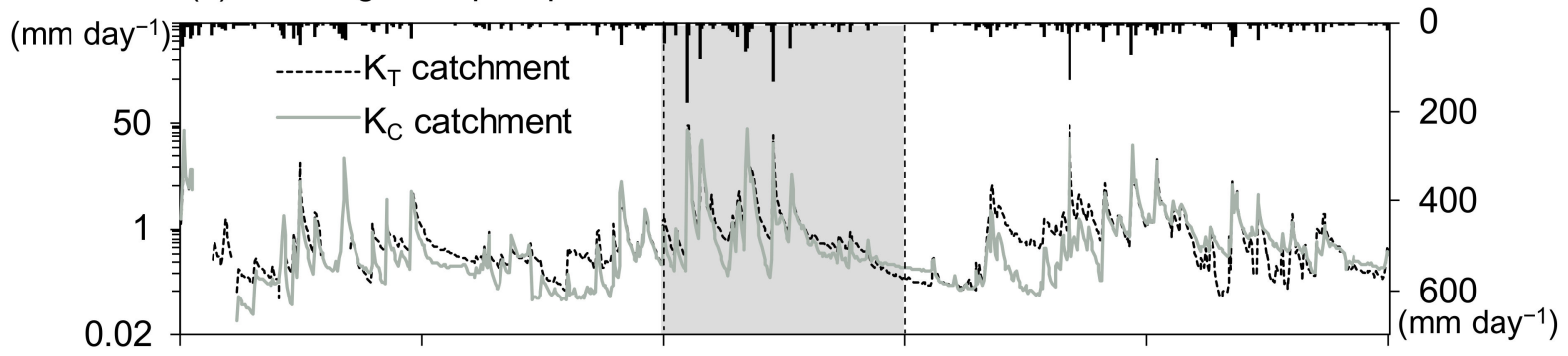

(b) Daily maximum stream temperature

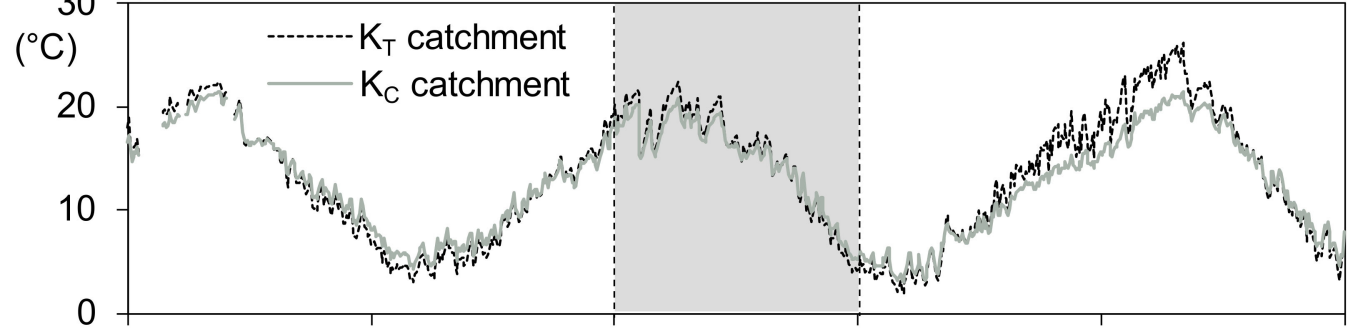

(c) Daily mean stream temperature

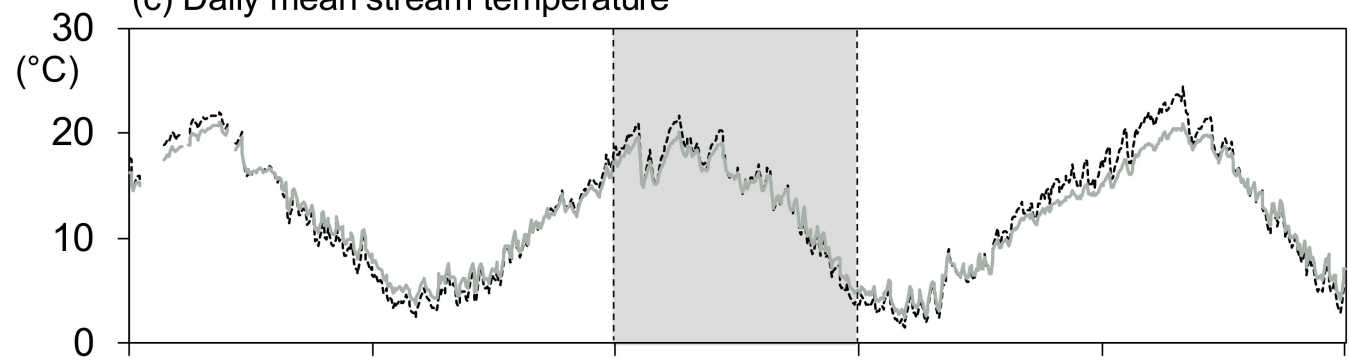

(d) Daily minimum stream temperature

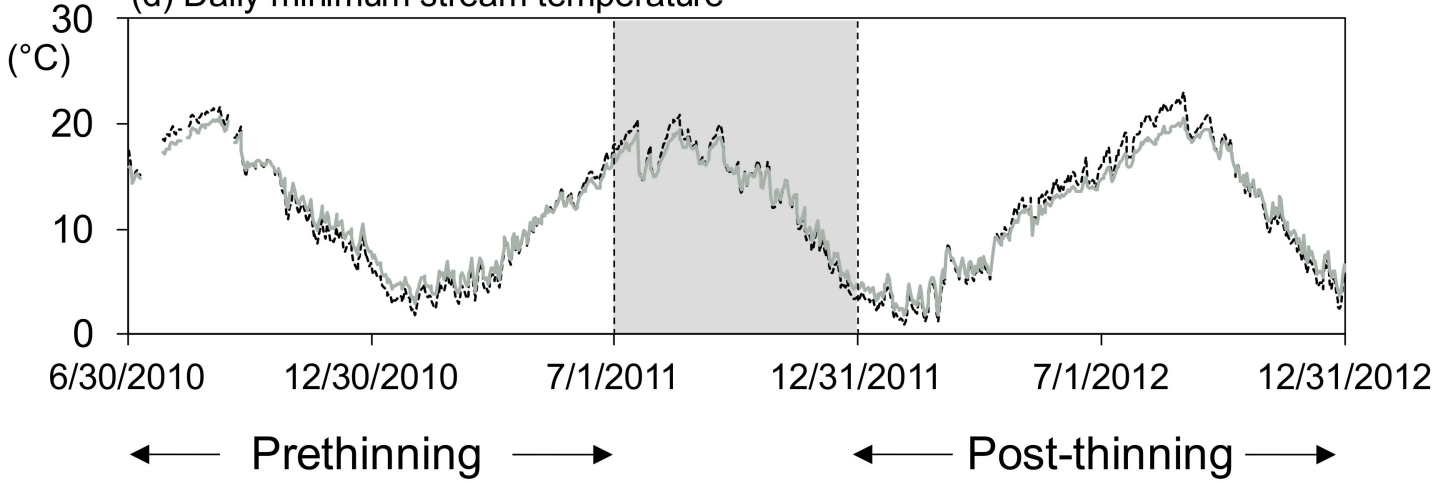

Figure 4. (a) Daily stream discharge and total daily precipitation, (b) daily maximum stream temperatures, (c) daily mean stream temperatures, and (d) daily minimum stream temperatures at the $\mathrm{K}_{\mathrm{T}}$ and $\mathrm{K}_{\mathrm{C}}$ catchments. Shaded area indicates during thinning operation period.

Daily stream temperature in the $\mathrm{K}_{\mathrm{T}}$ and $\mathrm{K}_{\mathrm{C}}$ catchments varied seasonally, with minimum temperatures occurring in January and February and maximum temperatures in August or September (Figure 4). Daily mean and maximum stream temperatures in the control catchment were generally similar in the pre- and post-thinning periods (Table 1). The daily mean stream temperature of the $\mathrm{K}_{\mathrm{T}}$ catchment was warmer in the post-thinning period, with the mean stream temperature ranging from $11.5^{\circ} \mathrm{C}$ in the prethinning to $12.2^{\circ} \mathrm{C}$ in the post-thinning period. The maximum temperature of $\mathrm{K}_{\mathrm{T}}$ catchment in the post-thinning period was higher than in the prethinning period. Daily minimum stream temperature of control and treated catchments were cooler than in the prethinning period. 
Observed minimum stream temperature in our study site remained above $0{ }^{\circ} \mathrm{C}$ even when air temperatures were lower than $-1{ }^{\circ} \mathrm{C}$.

\subsection{Treatment Effects}

The prethinning regressions provided good fits to the data, with residual standard errors of $0.21^{\circ} \mathrm{C}, 0.14{ }^{\circ} \mathrm{C}$, and $0.17{ }^{\circ} \mathrm{C}$ for daily maximum, mean, and minimum temperature, respectively. The prethinning calibration equations were all highly significant ( $p$-values $<0.001)$ and regression coefficients were similar for daily maximum, mean, and minimum stream temperatures (Table 2). The autoregression coefficients for the residuals were significant up to five or six lags. Treatment effects were greatest for daily maximum temperature, lowest for daily minimum temperature, and intermediate for daily mean temperature (Table 3).

Table 2. Results of ARIMAX analysis for prethinning calibration.

\begin{tabular}{|c|c|c|c|c|c|c|c|c|c|c|c|}
\hline \multirow{2}{*}{$\begin{array}{c}\text { Stream Temperature } \\
\text { Variables }\end{array}$} & \multicolumn{4}{|c|}{$b$ Estimates } & \multirow[b]{2}{*}{$k$} & \multirow{2}{*}{$\begin{array}{c}\hat{\rho_{1}} \\
\text { (s.e.) }\end{array}$} & \multirow{2}{*}{$\begin{array}{c}\hat{\rho_{2}} \\
\text { (s.e.) }\end{array}$} & \multirow{2}{*}{$\begin{array}{c}\hat{\rho_{3}} \\
\text { (s.e.) }\end{array}$} & \multirow{2}{*}{$\begin{array}{c}\hat{\rho_{4}} \\
\text { (s.e.) }\end{array}$} & \multirow{2}{*}{$\begin{array}{c}\hat{\rho_{5}} \\
\text { (s.e.) }\end{array}$} & \multirow{2}{*}{$\begin{array}{c}\hat{\rho_{6}} \\
\text { (s.e.) }\end{array}$} \\
\hline & $\begin{array}{l}\text { Intercept } \\
\text { (s.e.) }\end{array}$ & $\begin{array}{c}\mathrm{K}_{\mathrm{C}} \\
\text { (s.e.) }\end{array}$ & $\begin{array}{l}\text { Sine } \\
\text { (s.e.) }\end{array}$ & $\begin{array}{c}\text { Cosine } \\
\text { (s.e.) }\end{array}$ & & & & & & & \\
\hline Daily maximum & $\begin{array}{l}-1.51 \\
(0.27)\end{array}$ & $\begin{array}{c}1.11 \\
(0.02)\end{array}$ & $\begin{array}{c}0.04 \\
(0.12)\end{array}$ & $\begin{array}{l}-0.58 \\
(0.11)\end{array}$ & 6 & $\begin{array}{l}0.522 \\
(0.06)\end{array}$ & $\begin{array}{c}0.03 \\
(0.07)\end{array}$ & $\begin{array}{c}0.05 \\
(0.06)\end{array}$ & $\begin{array}{l}-0.06 \\
(0.06)\end{array}$ & $\begin{array}{c}0.08 \\
(0.06)\end{array}$ & $\begin{array}{c}0.13 \\
(0.06)\end{array}$ \\
\hline Daily mean & $\begin{array}{c}-1.94 \\
(0.2)\end{array}$ & $\begin{array}{c}1.14 \\
(0.02)\end{array}$ & $\begin{array}{c}0.33 \\
(0.15)\end{array}$ & $\begin{array}{l}-0.42 \\
(0.01)\end{array}$ & 5 & $\begin{array}{c}0.8 \\
(0.06)\end{array}$ & $\begin{array}{l}-0.13 \\
(0.07)\end{array}$ & $\begin{array}{c}0.07 \\
(0.07)\end{array}$ & $\begin{array}{l}-0.05 \\
(0.07)\end{array}$ & $\begin{array}{c}0.15 \\
(0.06)\end{array}$ & - \\
\hline Daily minimum & $\begin{array}{l}-1.64 \\
(0.22)\end{array}$ & $\begin{array}{l}1.12 \\
(0.02)\end{array}$ & $\begin{array}{c}0.27 \\
(0.12)\end{array}$ & $\begin{array}{l}-0.51 \\
(0.12)\end{array}$ & 6 & $\begin{array}{c}0.64 \\
(0.06)\end{array}$ & $\begin{array}{c}0.06 \\
(0.07)\end{array}$ & $\begin{array}{l}-0.03 \\
(0.07)\end{array}$ & $\begin{array}{c}0.04 \\
(0.07)\end{array}$ & $\begin{array}{c}0.03 \\
(0.07)\end{array}$ & $\begin{array}{c}0.1 \\
(0.06)\end{array}$ \\
\hline
\end{tabular}

$k$ is order of the residual autocorrelation, $\hat{\rho}_{i}$ is the estimated lag $i$ autocorrelation coefficient of residuals. The regression coefficients $b$ are estimated for the parameters $\beta$ with standard errors (s.e.) shown in brackets.

Table 3. Summary of residuals of prethinning regression, treatment effects, and the significance of treatment effects.

\begin{tabular}{|c|c|c|c|c|c|c|c|c|c|c|c|}
\hline \multirow{3}{*}{$\begin{array}{c}\text { Stream Temperature } \\
\text { Variables }\end{array}$} & \multicolumn{4}{|c|}{ Residuals $\left({ }^{\circ} \mathrm{C}\right)$} & \multicolumn{4}{|c|}{ Treatment Effects $\left(\mathrm{T}_{\mathrm{e}}\right)\left({ }^{\circ} \mathrm{C}\right)$} & \multicolumn{3}{|c|}{ Significance of $T_{e}$} \\
\hline & \multicolumn{4}{|c|}{$\begin{array}{c}\text { Prethinning } \\
(n=339)\end{array}$} & \multicolumn{4}{|c|}{$\begin{array}{l}\text { Post-Thinning } \\
(n=366)\end{array}$} & \multirow[t]{2}{*}{$k$} & \multirow[t]{2}{*}{$z$-Score } & \multirow[t]{2}{*}{$p$-Value } \\
\hline & Max & Mean & SD & Min & Max & Mean & SD & Min & & & \\
\hline Daily maximum & 0.9 & 0.0 & 0.2 & -1.5 & 3.9 & 1.3 & 1.0 & -0.2 & 240 & 85 & $<0.001$ \\
\hline Daily mean & 0.7 & 0.0 & 0.2 & -0.7 & 2.5 & 0.8 & 0.5 & -0.2 & 235 & 83 & $<0.001$ \\
\hline Daily minimum & 0.7 & 0.0 & 0.3 & -0.9 & 1.7 & 0.5 & 0.4 & -0.5 & 124 & 40 & $<0.001$ \\
\hline
\end{tabular}

$k$ is the observed number of exceedences, $n$ is the sample size.

Between 1 January to 22 September 2012, treatment effects exceeded the $95 \%$ prediction interval for a total of 240 days for daily maximum temperature, 235 days for daily mean temperature, and 124 days for daily minimum temperature (Figure 5). Treatment effects were highly significant for all three stream temperature variables (Table 3 ). The maximum treatment effect for maximum daily stream temperature was $3.9{ }^{\circ} \mathrm{C}$, which occurred on 27 August 2012, when maximum air temperature was $37.6{ }^{\circ} \mathrm{C}$ and daytime mean solar radiation was $412 \mathrm{Wm}^{-2}$. Maximum treatment effects for daily mean and minimum stream temperature were $2.5^{\circ} \mathrm{C}$ and $1.7{ }^{\circ} \mathrm{C}$, respectively, and occurred on 31 August 2012 , when maximum air temperature was $38.6^{\circ} \mathrm{C}$ and daytime mean solar radiation was $411 \mathrm{Wm}^{-2}$. 

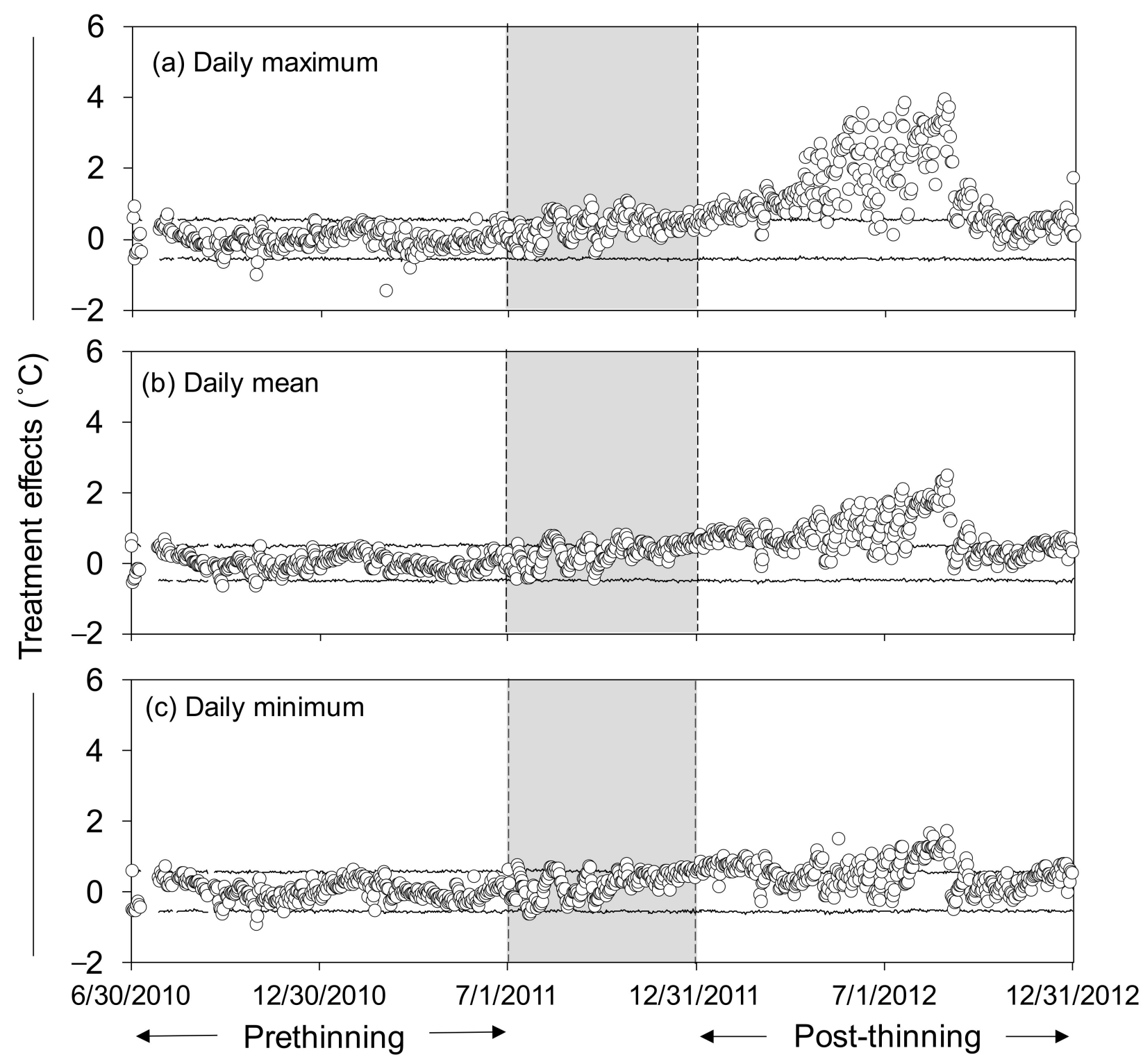

Figure 5. Time series of treatment effects for (a) daily maximum stream temperature, (b) daily mean stream temperature, and (c) daily minimum stream temperature at the $\mathrm{K}_{\mathrm{T}}$ catchment. The black horizontal lines indicated $95 \%$ prediction intervals for treatment effects. Shaded area indicates during thinning operation period.

\subsection{Analysis of Factors Controlling the Magnitude of Treatment Effects}

Solar radiation, air temperature, and air vapor pressure were positively correlated with treatment effects for daily maximum and mean temperature (Table 4). Air temperature and air vapor pressure showed a significant positive correlation with treatment effects for daily minimum stream temperature. Stream discharge was strongly negatively correlated with treatment effects for daily maximum, mean, and minimum temperature (Table 4). When all explanatory variables were correlated among each other, air temperature was shown to be strongly positively correlated with air vapor pressure and solar radiation.

Multiple linear regression results identified solar radiation as the primary hydrometeorological control on the variability of treatment effects for daily maximum temperature (Table 5). Discharge had a significant negative relation with treatment effects, whereas air vapor pressure had significant positive effects. For daily mean stream temperature, stream discharge had the largest effect on the treatment effect in terms of the magnitude of 
the standardized coefficient, followed by air vapor pressure. For daily minimum stream temperature, stream discharge and air vapor pressure were significant influences on the treatment effect, with negative and positive coefficients, respectively.

Table 4. Spearman rank correlation coefficients between treatment effects and hydrometeorological variables.

\begin{tabular}{cccccc}
\hline & Solar Radiation & Air Temperature & Air Vapor Pressure & Wind Speed & Discharge \\
\hline Daily maximum & $0.61^{* *}$ & $0.47^{* *}$ & $0.37^{* * *}$ & 0.07 & $-0.31^{* *}$ \\
Daily mean & $0.35^{* *}$ & $0.52^{* *}$ & $0.48^{* * *}$ & 0.09 & $-0.45^{* *}$ \\
Daily minimum & 0.03 & $0.44^{* *}$ & $0.47^{* * *}$ & $0.21^{*}$ & $-0.55^{* *}$ \\
Solar radiation & 1 & $0.4^{* *}$ & 0.04 & $0.31^{* *}$ & -0.03 \\
Air temperature & & 1 & $0.9^{* * *}$ & $0.11^{*}$ & $-0.25^{*}$ \\
Air vapor pressure & & & & 0.01 & $-0.21^{*}$ \\
Wind speed & & & & 1 & $-0.21^{*}$ \\
Discharge & & & & 1 \\
\hline
\end{tabular}

Significance level: ${ }^{*} p$-value $<0.05,{ }^{* *} p$-value $<0.01,{ }^{* * *} p$-value $<0.001, n=183$.

Table 5. Summary of multiple linear regression analysis with data from April to September 2012.

\begin{tabular}{clcccc}
\hline Treatment Effects & \multicolumn{1}{c}{ Explanatory Variables } & Standardized Coefficients & SE & $t$-Value & $p$-Value \\
\hline \multirow{3}{*}{ Daily maximum } & Daytime mean solar radiation & 0.55 & 0.051 & 10.80 & $<0.001$ \\
& Daily stream discharge & -0.3 & 0.051 & -5.71 & $<0.001$ \\
& Daytime mean air vapor pressure & 0.26 & 0.055 & 3.67 & $<0.001$ \\
\hline \multirow{3}{*}{ Daily mean } & Daily stream discharge & -0.47 & 0.055 & -8.55 & $<0.001$ \\
& Daytime mean air vapor pressure & 0.32 & 0.053 & 5.95 & $<0.001$ \\
& Daytime mean solar radiation & 0.26 & 0.054 & 4.98 & $<0.001$ \\
\hline \multirow{2}{*}{ Daily minimum } & Daily stream discharge & -0.53 & 0.056 & -9.55 & $<0.001$ \\
& Daytime mean air vapor pressure & 0.32 & 0.056 & 5.72 & $<0.001$ \\
\hline
\end{tabular}

SE indicates standard error.

The highest treatment effects for daily maximum stream temperature occurred under conditions of both low flow $\left(<1 \mathrm{~mm} \mathrm{day}^{-1}\right)$ and high solar radiation $\left(>400 \mathrm{Wm}^{-2}\right)$, while moderate flows (from 1 to $5 \mathrm{~mm}$ day $^{-1}$ ) tended to be associated with lower treatment effects even at high levels of solar radiation (Figure 6a). During the period of high air temperature $\left(20\right.$ to $\left.28^{\circ} \mathrm{C}\right)$ and high solar radiation $\left(400\right.$ to $\left.530 \mathrm{Wm}^{-2}\right)$, moderate discharges from 1 to $5 \mathrm{~mm}$ day $^{-1}$ reduced the mean of maximum treatment effects from 3.4 to $2.6^{\circ} \mathrm{C}$. Similarly, for a given intensity of solar radiation inputs, the treatment effect decreased with increases in stream discharge (Figure $6 b$ ).

Treatment effects exhibited distinctive variations during storm events and recession periods. Following a storm event from 5 July to 8 July 2012, solar radiation inputs for the next two days (9 July and 10 July 2012) were high: 458 and $476 \mathrm{Wm}^{-2}$. However, treatment effects were only 1.6 to $2.2{ }^{\circ} \mathrm{C}$ because discharge was 5 to 10 times higher during the hydrograph recession period compared to low flow conditions (Figure $7 \mathrm{~b}$ ). Lower treatment effects during recession periods also occurred on 1 June and 2 June 2012 (Figure 7a). Treatment effects became 2.3 and $3.2{ }^{\circ} \mathrm{C}$ when discharge became similar to prestorm conditions on 15 July and 16 July 2012. When rainfall was too low to produce significant catchment runoff, treatment effects progressively increased after each storm event and reached the highest treatment effect on 27 August 2012 (Figure 7c). 
(a) Daytime mean solar radiation

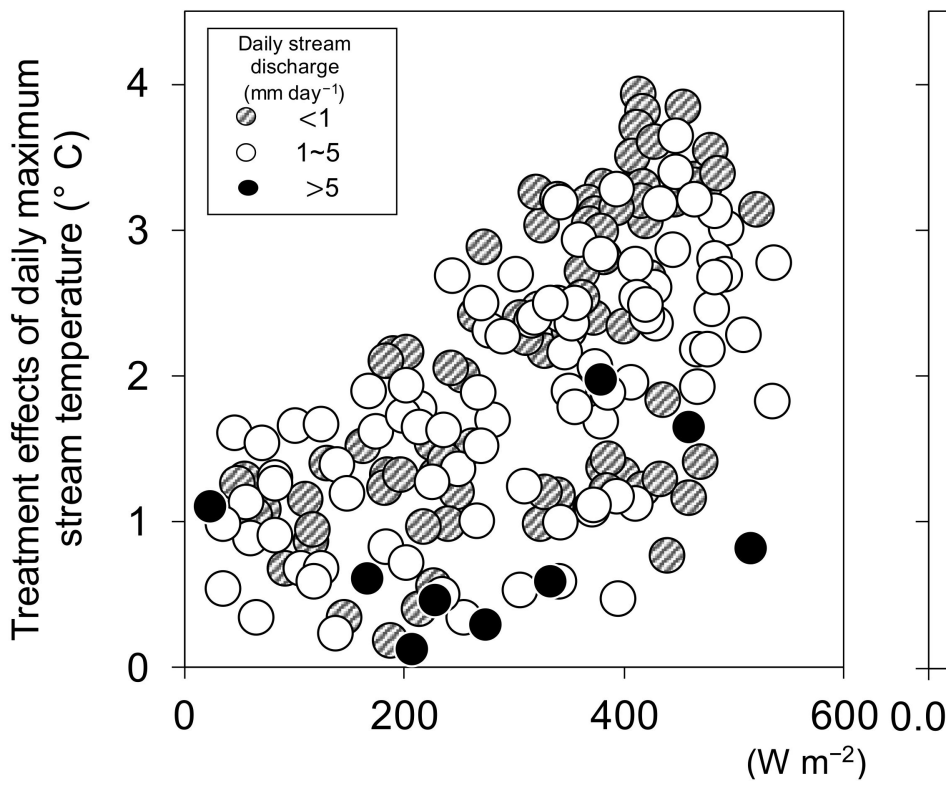

(b) Stream discharge

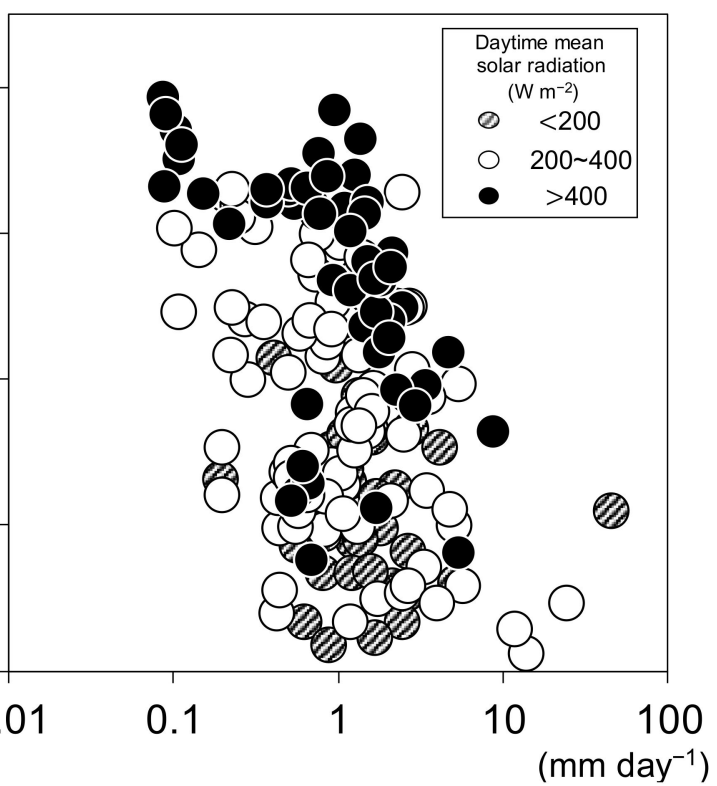

Figure 6. (a) Relationship between daytime mean solar radiation and treatment effects of daily maximum stream temperature by the classification of discharge classes. (b) Relationship between stream discharge and treatment effects of daily maximum stream temperature by the classification of solar radiation classes. Data from April to September 2012 were used for these plots.

(a) Period 1

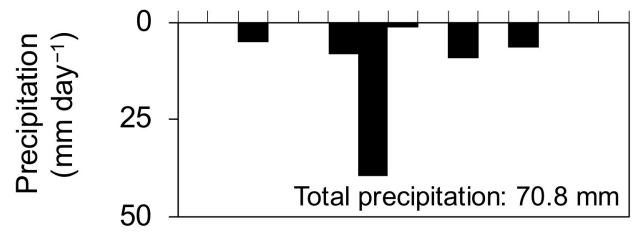



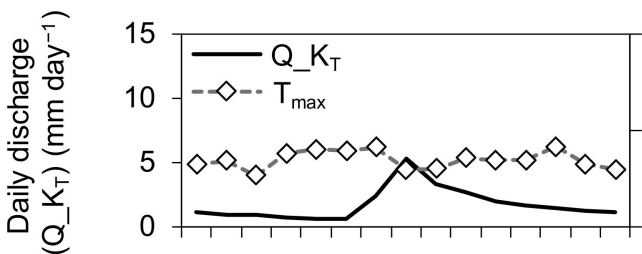

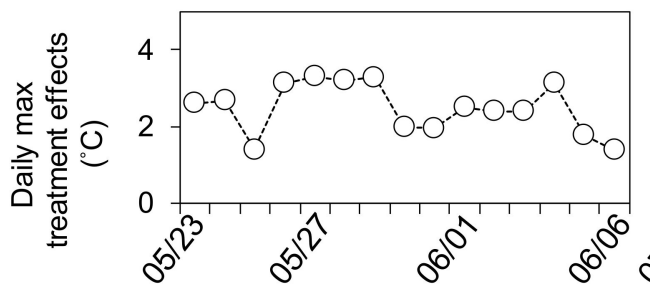

(b) Period 2
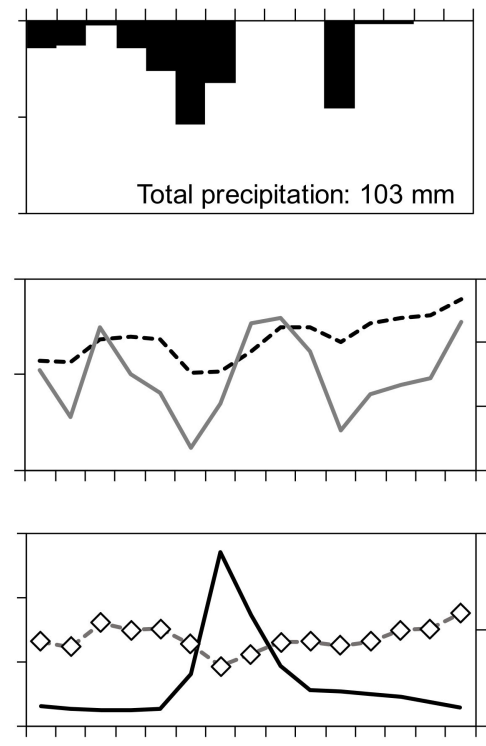

(c) Period 3
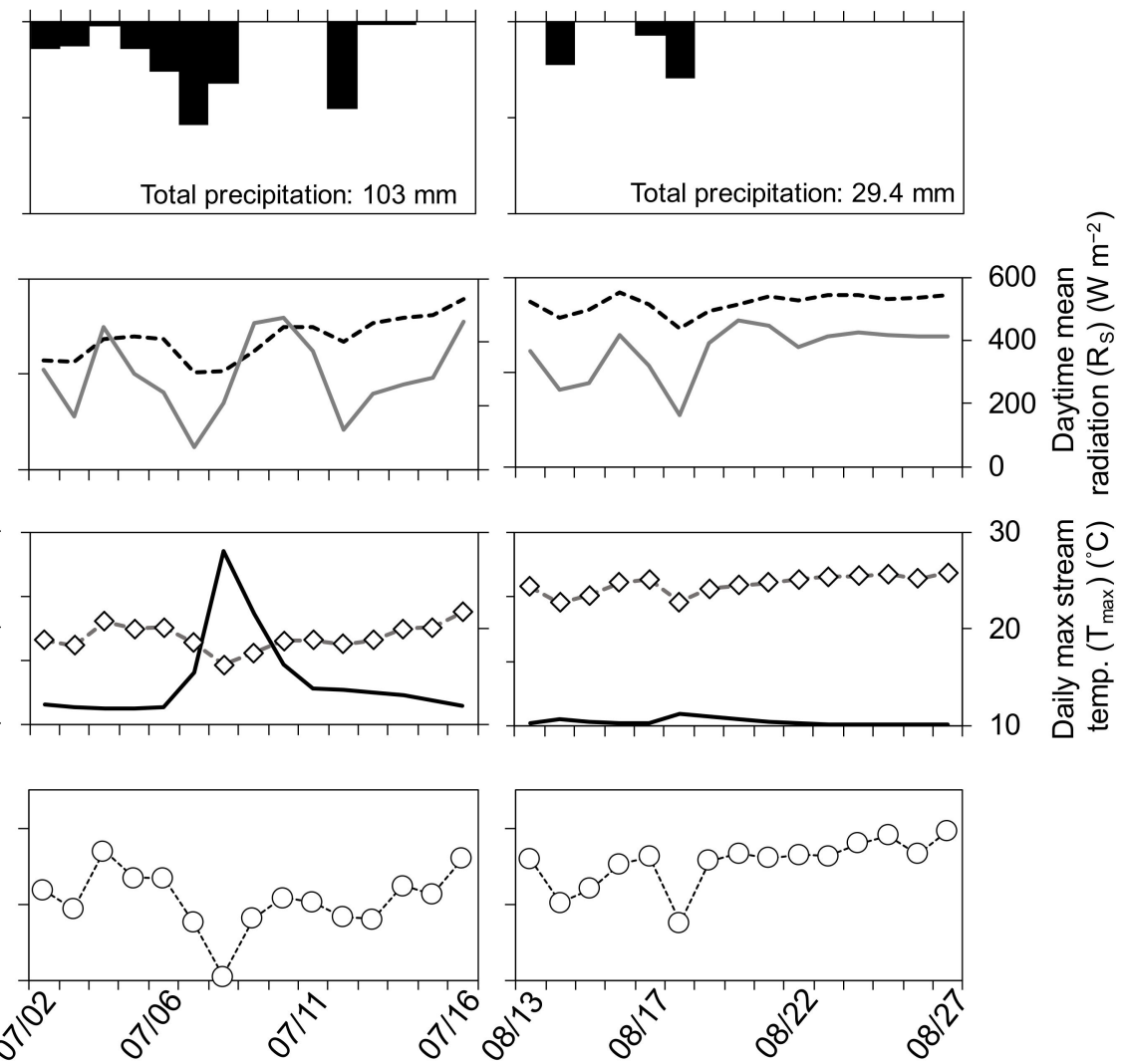

Figure 7. Changes in precipitation, runoff, climate condition, and treatment effect in selected periods of May (a), July (b), and August (c) in the post-thinning period. (a) Period 1 from 23 May to 6 June 2012 had less increase in discharge, (b) period 2 from 2 July to 16 July 2012, discharge increased significantly after storm events, and (c) period 3 from 13 August to 27 August 2012 had low rainfall and discharge. 


\section{Discussion}

\subsection{Effects of Riparian Forest Practices on Stream Temperature Responses}

The paired-catchment methodology is a well-established research approach because it allows the separation of harvesting effects from climate effects. Therefore, this approach is more accurate in elucidating the impacts of forest harvesting on stream temperature than other approaches, such as spatial comparations or before-after studies with no control catchment. Based on a paired-catchment experimental approach, our study revealed that $50 \%$ strip-thinning significantly increased daily maximum, mean, and minimum stream temperature for the first year following harvesting. Canopy openness increased by $8 \%$ following thinning, producing increases in maximum daily stream temperature of up to $3.9^{\circ} \mathrm{C}$. Similar percentages of riparian canopy removal using different harvesting practices induced similar order of magnitude of changes in stream temperatures, although the patterns of canopy openness were different between strip-thinning and random thinning. For instance, based on a study in a 90-ha headwater catchment, Ontario, Canada, Kreutzweiser et al. [31] found that 50\% random thinning in the riparian forest and resultant decreases in canopy openness from $86.3 \%$ to $83.9 \%$ elevated maximum temperature up to $4.4{ }^{\circ} \mathrm{C}$. Guenther et al. [23] showed that $50 \%$ random thinning in a 10-ha headwater catchment decreased canopy closure by $14 \%$ and increased daily maximum stream temperature by up to $5.5^{\circ} \mathrm{C}$. Rex et al. [50] showed that partial harvesting with retention at least 10 trees per $100 \mathrm{~m}$ of channel length reduced stream shade by $50 \%$ and increased mean weekly maximum stream temperature by up to $6^{\circ} \mathrm{C}$.

Increases in stream temperature by strip-thinning had less impact on stream temperatures than clear-cut harvesting without riparian buffers, which has produced increases in daily maximum temperature of up to $11^{\circ} \mathrm{C}[10,18,21,51]$. However, thermal response to strip thinning was higher compared to harvesting with retention of riparian buffers. For instance, streams with 30-m-wide riparian buffers exhibited negligible elevation of maximum daily stream temperature after clear-cutting in headwater streams in British Columbia [52], while retention of 10-m-wide buffers kept warming to less than $2{ }^{\circ} \mathrm{C}$ [18]. Bladon et al. [53] showed that streams with 15-m-wide riparian buffers did not increase in daily mean stream temperature after forest harvesting in Needle Branch, Oregon Coast Range. Reiter et al. [54] showed that a headwater stream with a 15.2-m-wide buffer had no apparent stream temperature increases after forest thinning in the Trask River Watershed Study, Oregon Coast Range.

Contemporary forest harvesting practices typically cause less disturbance to riparian vegetation and soil compared to practices that were common until the 1980s, which often involved clear-cut harvesting with no riparian buffer and broadcast burning of slash. Because riparian vegetation and soil tend to be less disturbed by partial stand removal [55], availability of understory vegetation can help mitigate solar radiation inputs to streams under strip and random thinning or variable retention harvesting treatments $[9,56]$. Indeed, Gomi et al. [18] found that rapid thermal recovery among clear-cut channels was associated with recovery of understory vegetation.

\subsection{Temporal Variability of Treatment Effects and Influence of Catchment Hydrology}

Similar to previous studies in rain-dominated catchments, the treatment effects were low in winter and high in summer and were greater for daily maximum temperature compared to daily minimum temperature $[18,23]$. These patterns are consistent with solar radiation being a primary driver of postharvest warming. However, whereas the Pacific Northwest experiences seasonal low flows during summer and early autumn, the monsoon and typhoon seasons can produce moderate to high flows through most of the period of high stream temperature at these Japanese study sites.

Multiple linear regression analysis revealed that solar radiation had the largest impact on variations in treatment effects for daily maximum stream temperature. This finding is consistent with previous process-based studies identifying net radiation as the dominant component of total daytime energy exchange following forest harvesting $[25,57]$. Air tem- 
perature was positively correlated with treatment effects. This relation could reflect the direct influence of air temperature on energy inputs via sensible heat flux and incident longwave radiation. However, the relation could also reflect an indirect influence due to the significant correlation between air temperature and solar radiation. Air temperature was not included in the results of the multiple linear regression because it exhibited a collinearity with air vapor pressure $(\mathrm{VIF}=17)$. The treatment effect had a positive relationship with the vapor pressure of the air, which is consistent with the influence of vapor pressure of air on energy inputs via the latent heat flux [58-60].

Stream discharge influenced the magnitudes of treatment effects for maximum, minimum, and mean daily stream temperatures. In particular, for maximum daily stream temperature, treatment effects under moderate discharges (from 1 to $5 \mathrm{~mm} \mathrm{day}^{-1}$ ) tended to be lower than increases under lower discharges $\left(<1 \mathrm{~mm} \mathrm{day}^{-1}\right)$. Similar to our findings, Janisch et al. [19] showed that the highly variable response of daily maximum stream temperature in clear-cut streams, from 0.2 to $3.6^{\circ} \mathrm{C}$, was not simply related to the effects of meteorological factors such as solar radiation inputs, but also depended on stream flow. Higher discharge may influence the treatment effect in three ways: (1) discharge is associated with water depth, which reduces stream thermal response to energy inputs; (2) increased discharge is associated with higher velocity and thus shorter residence time within channel reaches, which reduces the opportunity for heating; and (3) hillslope runoff is associated with advective heat transport, which influences the stream heat budget [61].

Forest harvesting can modify flow volume and hydrologic pathways from hillslopes, and thus may influence the magnitude of treatment effects. Based on detailed investigation in our study catchments, reduction of interception loss and transpiration after 50\% stripthinning increased the amount of water reaching the ground surface and soil matrix [62,63]. Therefore, combined effects of changes in runoff and solar radiation input need to be included for the analysis of effects of timber harvesting on stream temperature response.

Mixing of thermally stable and relatively cool deep soil water and/or groundwater during high flow events and hydrograph recession periods likely reduced the treatment effects in our study catchment $[64,65]$. Indeed, the influence of mixing water from various flow pathways on changes in stream temperature was confirmed by detailed monitoring in a headwater catchment in Ashiu, Japan [66]. Differences in the contribution of groundwater inflow to streams with different geology also need to be considered [5,20,67]. Nevertheless, dynamics of mixing subsurface and groundwater related to catchment internal hydrological processes is also an important factor for controlling the variability of treatment effects. Most previous process-based research on forestry and stream temperature focused on the effects of forest removal on stream-surface energy exchanges, especially solar radiation (e.g., $[9,57])$. However, the results of this study have highlighted the important role of catchment hydrology as a control on stream thermal responses to forestry.

\section{Conclusions}

The first objective of this study was to quantify the impacts of strip-thinning on stream temperature in a forested headwater catchment. Paired-catchment analysis was used to meet the first objective and demonstrated that removal of $50 \%$ of a forest stand by stripthinning in a headwater catchment changed stream temperatures the first year following treatment. Maximum daily stream temperature increased up to $3.9{ }^{\circ} \mathrm{C}$, which was similar to increases following 50\% random thinning and variable retention harvesting in previous studies, but was greater than the effect of clear-cutting with retention of riparian buffers.

The findings obtained in this study support the second objective and demonstrated that the thermal response varied positively with solar radiation and negatively with stream discharge. Stream discharge response to rain events played a key role in moderating the heating associated with solar radiation inputs. Furthermore, our study site had frequent precipitation during summer associated with its Asian monsoon climate, in contrast to most previous studies, which were conducted at sites in North America and Europe that experience relatively dry summers. 
These findings highlight the need for future studies focusing on sites with a broader range of climate, geology, and groundwater-surface water interactions to develop a fuller understanding of thermal responses to timber harvesting in headwater catchments.

Author Contributions: Conceptualization, resources, and supervision, T.G.; methodology, T.G., R.D.M., and D.Q.O.; validation, T.G. and R.D.M.; investigation, data curation, and writing_original draft preparation, D.Q.O.; writing—review and editing, all coauthors. All authors have read and agreed to the published version of the manuscript.

Funding: This study was supported by the Japan Science and Technology (JST), Core Research for Evolutional Science and Technology (CREST) projects entitled "Field and modeling studies on the effect of forest devastation on flooding and environmental issues" and "Development of Innovative Technologies for Increasing in Watershed Runoff and Improving River Environment by Management Practice of Devastated Forest Plantation". Part of this study was supported by the Japan Society for Promotion of Science (Grant No. 16H02556).

Institutional Review Board Statement: Not applicable.

Informed Consent Statement: Not applicable.

Data Availability Statement: The data that support the findings of this study are available from the corresponding author, upon reasonable request.

Acknowledgments: We would like to thank the staffs of the Field Museum Karasawa, Tokyo University of Agriculture and Technology (TUAT). We also wish to thank all lab members of the Watershed Hydrology and Ecosystems Management Laboratory, TUAT for supporting field investigation and advice on this study.

Conflicts of Interest: The authors declare no conflict of interest.

\section{References}

1. Becker, M.W.; Georgian, T.; Ambrose, H.; Siniscalchi, J.; Fredrick, K. Estimating flow and flux of ground water discharge using water temperature and velocity. J. Hydrol. 2004, 296, 221-233. [CrossRef]

2. Westhoff, M.C.; Gooseff, M.N.; Bogaard, T.A.; Savenije, H.H.G. Quantifying hyporheic exchange at high spatial resolution using natural temperature variations along a first-order stream. Water Resour. Res. 2011, 47, W10508. [CrossRef]

3. Gomi, T.; Sidle, R.C.; Richardson, J.S. Understanding processes and downstream linkages of headwater systems. Bioscience 2002, 52, 905-916. [CrossRef]

4. Webb, B.W.; Clack, P.D.; Walling, D.E. Water-air temperature relationships in a Devon river system and the role of flow. Hydrol. Process. 2003, 17, 3069-3084. [CrossRef]

5. Tague, C.; Farrell, M.; Grant, G.; Lewis, S.; Rey, S. Hydrogeologic controls on summer stream temperatures in the McKenzie River basin, Oregon. Hydrol. Process. 2007, 21, 3288-3300. [CrossRef]

6. Leach, J.A.; Moore, R.D.; Hinch, S.G.; Gomi, T. Estimation of forest harvesting-induced stream temperature changes and bioenergetic consequences for cutthroat trout in a coastal stream in British Columbia, Canada. Aquat. Sci. 2012, 74, 427-441. [CrossRef]

7. Richardson, J.S. Biological Diversity in Headwater Streams. Water 2019, 11, 366. [CrossRef]

8. Webb, B.W.; Hannah, D.M.; Moore, R.D.; Brown, L.E.; Nobilis, F. Recent advances in stream and river temperature research. Hydrol. Process. 2008, 22, 902-918. [CrossRef]

9. Moore, R.D.; Spittlehouse, D.L.; Story, A. Riparian microclimate and stream temperature response to forest harvesting: A review. J. Am. Water Resour. Assoc. 2005, 41, 813-834. [CrossRef]

10. Harris, D.D. Hydrologic Changes after Logging in two Small Oregon Coastal Watersheds; Department of the Interior, Geological Survey: Burlington, MA, USA, 1977; Volume 2037. [CrossRef]

11. Webb, B.W.; Crisp, D.T. Afforestation and stream temperature in a temperate maritime environment. Hydrol. Process. 2006, 20, 51-66. [CrossRef]

12. Carlson, K.M.; Curran, L.M.; Ponette-Gonzalez, A.G.; Ratnasari, D.; Lisnawati, N.; Purwanto, Y.; Brauman, K.A.; Raymond, P.A. Influence of watershed-climate interactions on stream temperature, sediment yield, and metabolism along a land use intensity gradient in Indonesian Borneo. J. Geophys. Res. Biogeo. 2014, 119, 1110-1128. [CrossRef]

13. Raulerson, S.; Jackson, C.R.; Melear, N.D.; Younger, S.E.; Dudley, M.; Elliott, K.J. Do southern Appalachian Mountain summer stream temperatures respond to removal of understory rhododendron thickets? Hydrol. Process. 2020, 34, 3045-3060. [CrossRef]

14. Wilkerson, E.; Hagan, J.M.; Siegel, D.; Whitman, A.A. The effectiveness of different buffer widths for protecting headwater stream temperature in Maine. Forest Sci. 2006, 52, 221-231. 
15. Groom, J.D.; Dent, L.; Madsen, L.J.; Fleuret, J. Response of western Oregon (USA) stream temperatures to contemporary forest management. Forest Ecol. Manag. 2011, 262, 1618-1629. [CrossRef]

16. Bowler, D.E.; Mant, R.; Orr, H.; Hannah, D.M.; Pullin, A.S. What are the effects of wooded riparian zones on stream temperature? Environ. Evid. 2012, 1, 1-9. [CrossRef]

17. Groom, J.D.; Johnson, S.L.; Seeds, J.D.; Ice, G.G. Evaluating Links Between Forest Harvest and Stream Temperature Threshold Exceedances: The Value of Spatial and Temporal Data. J. Am. Water Resour. Assoc. 2017, 53, 761-773. [CrossRef]

18. Gomi, T.; Moore, R.D.; Dhakal, A.S. Headwater stream temperature response to clear-cut harvesting with different riparian treatments, coastal British Columbia, Canada. Water Resour. Res. 2006, 42, W08437. [CrossRef]

19. Janisch, J.E.; Wondzell, S.M.; Ehinger, W.J. Headwater stream temperature: Interpreting response after logging, with and without riparian buffers, Washington, USA. Forest Ecol. Manag. 2012, 270, 302-313. [CrossRef]

20. Bladon, K.D.; Segura, C.; Cook, N.A.; Bywater-Reyes, S.; Reiter, M. A multicatchment analysis of headwater and downstream temperature effects from contemporary forest harvesting. Hydrol. Process. 2018, 32, 293-304. [CrossRef]

21. Johnson, S.L.; Jones, J.A. Stream temperature responses to forest harvest and debris flows in western Cascades, Oregon. Can. J. Fish. Aquat. Sci. 2000, 57, 30-39. [CrossRef]

22. Quinn, J.M.; Wright-Stow, A.E. Stream size influences stream temperature impacts and recovery rates after clearfell logging. Forest Ecol. Manag. 2008, 256, 2101-2109. [CrossRef]

23. Guenther, S.M.; Gomi, T.; Moore, R.D. Stream and bed temperature variability in a coastal headwater catchment: Influences of surface-subsurface interactions and partial-retention forest harvesting. Hydrol. Process. 2014, 28, 1238-1249. [CrossRef]

24. Leach, J.A.; Moore, D. Insights on stream temperature processes through development of a coupled hydrologic and stream temperature model for forested coastal headwater catchments. Hydrol. Process. 2017, 31, 3160-3177. [CrossRef]

25. Moore, R.D.; Sutherland, P.; Gomi, T.; Dhakal, A. Thermal regime of a headwater stream within a clear-cut, coastal British Columbia, Canada. Hydrol. Process. 2005, 19, 2591-2608. [CrossRef]

26. Hockey, J.; Owens, I.; Tapper, N. Empirical and theoretical models to isolate the effect of discharge on summer water temperatures in the Hurunui River. J. Hydrol. 1982, 21, 1-12.

27. Du, X.Z.; Goss, G.; Faramarzi, M. Impacts of Hydrological Processes on Stream Temperature in a Cold Region Watershed Based on the SWAT Equilibrium Temperature Model. Water 2020, 12, 1112. [CrossRef]

28. Vano, J.A.; Nijssen, B.; Lettenmaier, D.P. Seasonal hydrologic responses to climate change in the Pacific Northwest. Water Resour. Res. 2015, 51, 1959-1976. [CrossRef]

29. Swanson, F.J.; Franklin, J.F. New Forestry Principles from Ecosystem Analysis of Pacific-Northwest Forests. Ecol. Appl. 1992, 2, 262-274. [CrossRef]

30. Mitchell, S.J.; Beese, W.J. The retention system: Reconciling variable retention with the principles of silvicultural systems. For. Chron. 2002, 78, 397-403. [CrossRef]

31. Kreutzweiser, D.P.; Capell, S.S.; Holmes, S.B. Stream temperature responses to partial-harvest logging in riparian buffers of boreal mixedwood forest watersheds. Can. J. Forest Res. 2009, 39, 497-506. [CrossRef]

32. Maleque, M.A.; Ishii, H.T.; Maeto, K.; Taniguchi, S. Line thinning fosters the abundance and diversity of understory Hymenoptera (Insecta) in Japanese cedar (Cryptomeria japonica D. Don) plantations. J. Forest Res. 2007, 12, 14-23. [CrossRef]

33. Ishii, H.T.; Maleque, M.A.; Shingo, T.G. Line thinning promotes stand growth and understory diversity in Japanese cedar (Cryptomeria japonica D. Don) plantations. J. Forest Res. 2008, 13, 73-78. [CrossRef]

34. Kerr, G.; Haufe, J. Thinning Practice: A Silvicultural Guide. Forestry Commission. 2011. Available online: https://www. forestresearch.gov.uk/documents/4992/Silviculture_Thinning_Guide_v1_Jan2011.pdf (accessed on 5 April 2021).

35. Nam, S.; Hiraoka, M.; Gomi, T.; Dung, B.X.; Onda, Y.; Kato, H. Suspended-sediment responses after strip thinning in headwater catchments. Landsc. Ecol. Eng. 2016, 12, 197-208. [CrossRef]

36. Montgomery, D.R.; Buffington, J.M. Channel-reach morphology in mountain drainage basins. Geol. Soc. Am. Bull. 1997, 109, 596-611. [CrossRef]

37. Sun, X.C.; Onda, Y.; Kato, H.; Otsuki, K.; Gomi, T. Partitioning of the total evapotranspiration in a Japanese cypress plantation during the growing season. Ecohydrology 2014, 7, 1042-1053. [CrossRef]

38. Lopez-Vicente, M.; Sun, X.C.; Onda, Y.; Kato, H.; Gomi, T.; Hiraoka, M. Effect of tree thinning and skidding trails on hydrological connectivity in two Japanese forest catchments. Geomorphology 2017, 292, 104-114. [CrossRef]

39. Herschy, R.W. Streamflow Measurement; Elsevier Applied Science: New York, NY, USA, 1985.

40. Dung, B.X.; Gomi, T.; Miyata, S.; Sidle, R.C.; Kosugi, K.; Onda, Y. Runoff responses to forest thinning at plot and catchment scales in a headwater catchment draining Japanese cypress forest. J. Hydrol. 2012, 444, 51-62. [CrossRef]

41. Frazer, G.W.; Canham, C.D.; Lertzman, K.P. Gap Light Analyzer (GLA), Version 2.0: Imaging Software to Extract Canopy Structure and Gap Light Transmission Indices from True-Colour Fisheye Photographs, Users Manual and Program Documentation; Simon Fraser University: Burnaby, BC, Canada; The Institute of Ecosystem Studies: Millbrook, NY, USA, 1999; Volume 36.

42. Watson, F.; Vertessy, R.; McMahon, T.; Rhodes, B.; Watson, I. Improved methods to assess water yield changes from pairedcatchment studies: Application to the Maroondah catchments. Forest Ecol. Manag. 2001, 143, 189-204. [CrossRef]

43. Akaike, H. A new look at the statistical model identification. IEEE Trans. Automat. Control 1974, 19, 716-723. [CrossRef]

44. Som, N.A.; Zegre, N.P.; Ganio, L.M.; Skaugset, A.E. Corrected prediction intervals for change detection in paired watershed studies. Hydrolog. Sci. J. 2012, 57, 134-143. [CrossRef] 
45. Webb, B.W.; Zhang, Y. Spatial and seasonal variability in the components of the river heat budget. Hydrol. Process. 1997, 11, 79-101. [CrossRef]

46. MacDonald, R.J.; Boon, S.; Byrne, J.M.; Silins, U. A comparison of surface and subsurface controls on summer temperature in a headwater stream. Hydrol. Process. 2014, 28, 2338-2347. [CrossRef]

47. Greenacre, M.; Primicerio, R. Multivariate Analysis of Ecological Data; Fundacion BBVA: Bilbao, Spain, 2014; Available online: https:/ / www.fbbva.es/wp-content/uploads/2017/05/dat/DE_2013_multivariate.pdf (accessed on 5 April 2021).

48. Yamashita, T.; Yamashita, K.; Kamimura, R. A stepwise AIC method for variable selection in linear regression. Commun. Stat. Theor. M 2007, 36, 2395-2403. [CrossRef]

49. Neter, J.; Kutner, M.H.; Nachtsheim, C.J.; Wasserman, W. Applied Linear Statistical Models; McGraw-Hill/Irwin, WCB McGraw-Hill: New York, NY, USA, 1996; Volume 4.

50. Rex, J.F.; Maloney, D.A.; Krauskopf, P.N.; Beaudry, P.G.; Beaudry, L.J. Variable-retention riparian harvesting effects on riparian air and water temperature of sub-boreal headwater streams in British Columbia. Forest Ecol. Manag. 2012, 269, 259-270. [CrossRef]

51. Brown, G.W.; Krygier, J.T. Effects of clear-cutting on stream temperature. Water Resour. Res. 1970, 6, 1133-1139. [CrossRef]

52. Kiffney, P.M.; Richardson, J.S.; Bull, J.P. Responses of periphyton and insects to experimental manipulation of riparian buffer width along forest streams. J. Appl. Ecol. 2003, 40, 1060-1076. [CrossRef]

53. Bladon, K.D.; Cook, N.A.; Light, J.T.; Segura, C. A catchment-scale assessment of stream temperature response to contemporary forest harvesting in the Oregon Coast Range. Forest Ecol. Manag. 2016, 379, 153-164. [CrossRef]

54. Reiter, M.; Johnson, S.L.; Homyack, J.; Jones, J.E.; James, P.L. Summer stream temperature changes following forest harvest in the headwaters of the Trask River watershed, Oregon Coast Range. Ecohydrology 2020, 13, e2178. [CrossRef]

55. Bescond, H.; Fenton, N.J.; Bergeron, Y. Partial harvests in the boreal forest: Response of the understory vegetation five years after harvest. Forest Chron. 2011, 87, 86-98. [CrossRef]

56. Gravelle, J.A.; Link, T.E. Influence of timber harvesting on headwater peak stream temperatures in a northern Idaho watershed. Forest Sci. 2007, 53, 189-205.

57. Brown, G.W. Predicting temperatures of small streams. Water Resour. Res. 1969, 5, 68-75. [CrossRef]

58. Hannah, D.M.; Malcolm, I.A.; Soulsby, C.; Youngson, A.F. Heat exchanges and temperatures within a salmon spawning stream in the cairngorms, Scotland: Seasonal and sub-seasonal dynamics. River Res. Appl. 2004, 20, 635-652. [CrossRef]

59. Leach, J.A.; Moore, R.D. Above-stream microclimate and stream surface energy exchanges in a wildfire-disturbed riparian zone. Hydrol. Process. 2010, 24, 2369-2381. [CrossRef]

60. Szeitz, A.J.; Moore, R.D. Predicting evaporation from mountain streams. Hydrol. Process. 2020, 34, 4262-4279. [CrossRef]

61. Leach, J.A.; Moore, R.D. Winter stream temperature in the rain-on-snow zone of the Pacific Northwest: Influences of hillslope runoff and transient snow cover. Hydrol. Earth Syst. Sci. 2014, 18, 819-838. [CrossRef]

62. Sun, X.C.; Onda, Y.; Chiara, S.; Kato, H.; Gomi, T. The effect of strip thinning on spatial and temporal variability of throughfall in a Japanese cypress plantation. Hydrol. Process. 2015, 29, 5058-5070. [CrossRef]

63. Sun, X.C.; Onda, Y.; Otsuki, K.; Kato, H.; Gomi, T.; Liu, X.Y. Change in evapotranspiration partitioning after thinning in a Japanese cypress plantation. Trees Struct. Funct. 2017, 31, 1411-1421. [CrossRef]

64. Sidle, R.C.; Tsuboyama, Y.; Noguchi, S.; Hosoda, I.; Fujieda, M.; Shimizu, T. Stormflow generation in steep forested headwaters: A linked hydrogeomorphic paradigm. Hydrol. Process. 2000, 14, 369-385. [CrossRef]

65. Gomi, T.; Asano, Y.; Uchida, T.; Onda, Y.; Sidle, R.C.; Miyata, S.; Kosugi, K.; Mizugaki, S.; Fukuyama, T.; Fukushima, T. Evaluation of storm runoff pathways in steep nested catchments draining a Japanese cypress forest in central Japan: A geochemical approach. Hydrol. Process. 2010, 24, 550-566. [CrossRef]

66. Uchida, T.; Kosugi, K.; Mizuyama, T. Effects of pipe flow and bedrock groundwater on runoff generation in a steep headwater catchment in Ashiu, central Japan. Water Resour. Res. 2002, 38, 1119. [CrossRef]

67. Onda, Y.; Tsujimura, M.; Fujihara, J.I.; Ito, J. Runoff generation mechanisms in high-relief mountainous watersheds with different underlying geology. J. Hydrol. 2006, 331, 659-673. [CrossRef] 